\title{
The role of the pituitary gland and ACTH in the regulation of mRNAs encoding proteins essential for adrenal steroidogenesis in the late-gestation ovine fetus
}

\author{
P J Simmonds, I D Phillips, K R Poore, I D Coghill, I R Young \\ and B J Canny \\ Department of Physiology, Monash University, PO Box 13F, Clayton, Victoria 3800, Australia \\ (Requests for offprints should be addressed to B Canny; Email: ben.canny@med.monash.edu.au)
}

\begin{abstract}
To further understand the relative roles of the pituitary gland and ACTH in the regulation of mRNAs encoding proteins that are essential for adrenal development, we investigated the effects of, first, an ACTH infusion and labour in intact fetuses and, secondly, the effect of an ACTH infusion to fetuses with and without a pituitary gland, on the relative abundance of the mRNA encoding for the ACTH receptor (MC2R), steroidogenic factor 1 (SF-1), cholesterol side-chain cleavage enzyme ( $\left.\mathrm{P} 450_{\text {scc }}\right)$, $3 \beta$-hydroxysteroid dehydrogenase (3ßHSD) and $17 \alpha-$ hydroxylase $\left(\mathrm{P}^{4} 50_{\mathrm{C} 17}\right)$ in the fetal adrenal gland. $\mathrm{ACTH}_{1-24}$ infusion $(14.7 \mathrm{pmol} / \mathrm{kg}$ per h) to intact fetuses was without effect on the abundance of mRNA encoding MC2R and SF-1, irrespective of whether the infusion was given for 18 (115-132 days of gestation) or 32 days (115 days to term (147 days of gestation)). Hypophysectomy (HX) did not alter the expression of MC2R mRNA; however, the abundance of SF-1 mRNA fell by approximately $50 \%$ following the removal of the pituitary gland. $\mathrm{ACTH}_{1-24}$ infusion to HX fetuses failed to restore levels of SF-1 mRNA to that seen in intact animals. P450 $0_{\text {scc }}$ and $3 \beta \mathrm{HSD}$ mRNAs were increased by $\mathrm{ACTH}_{1-24}$ infusion for 18 days in intact animals, although no effects of the
\end{abstract}

infusion were seen on $\mathrm{P}^{4} 50_{\mathrm{C} 17}$ mRNA levels. For all three of these mRNAs, there was a significant increase in their abundance between 132 days of gestation and term in intact fetuses. By term, ACTH $\mathrm{A}_{1-24}$ infusion was without any additional effect on their abundance. HX decreased the expression of $\mathrm{P} 450_{\mathrm{scc}}, 3 \beta \mathrm{HSD}$ and $\mathrm{P} 450_{\mathrm{C} 17} \mathrm{mRNAs}$, while $\mathrm{ACTH}_{1-24}$ infusion to $\mathrm{HX}$ fetuses increased the expression of these mRNAs to levels seen in intact animals. There were significant correlations between the abundance of the mRNA for $\mathrm{P} 450_{\mathrm{scc}}, 3 \beta \mathrm{HSD}$ and $\mathrm{P} 450_{\mathrm{C} 17}$, but not MC2R and $\mathrm{SF}-1$, and premortem plasma cortisol concentrations. These results emphasise the importance of the pituitary gland and ACTH in the regulation of the enzymes involved in adrenal steroidogenesis. Factors in addition to ACTH may also play some role, as the infusion was not always effective in increasing the abundance of the mRNAs. Surprisingly, the mRNA for MC2R and SF-1 did not appear to be regulated by ACTH in the late-gestation ovine fetus, though a pituitary-dependent factor may be involved in the regulation of SF-1 mRNA abundance.

Journal of Endocrinology (2001) 168, 475-485

\section{Introduction}

A late-gestation increase in fetal glucocorticoid concentrations is a hallmark of fetal development in mammalian species, and plays a critical role in preparing the fetus for the transition to extrauterine life. In addition, for a number of species including the sheep, the increase in fetal cortisol production is also the critical trigger determining the timing of labour (Liggins \& Thorburn 1994).

A number of factors are thought to contribute to the increase in cortisol concentrations in the late-gestation fetal sheep, though our understanding of their relative importance is incomplete. It is clear that an intact hypothalamopituitary-adrenal (HPA) axis is critical for the normal cortisol surge and parturition, as disruption at any level of the axis results in decreased cortisol concentrations and a failure of parturition (Liggins et al. 1967, Drost \& Holm 1968, Antolovich et al. 1991, Myers et al. 1993). Furthermore, the infusion of pituitary adrenocorticotrophin $\left(\mathrm{ACTH}_{1-24}\right)$ or adrenal (cortisol) hormones of the HPA axis induces premature labour in intact fetuses, and restores cortisol concentrations and parturition in fetuses that have had lesions of these respective organs (Liggins \& Thorburn 1994, Poore et al. 1998). It is generally believed that increasing $\mathrm{ACTH}$ concentrations drive the increase in cortisol concentrations, though many studies have demonstrated only modest, linear increases in ACTH concentrations in the face of a large, exponential increase in 
cortisol (Norman et al. 1985, Deayton et al. 1994, Phillips et al. 1996, Canny et al. 1998, Poore et al. 1998). In addition, we have recently suggested that while the presence of ACTH is essential for the cortisol surge and parturition, an increase in the concentrations of the pituitary hormone is not a prerequisite for normal labour (Poore et al. 1998).

It is therefore clear that factors in addition to an increase in ACTH concentrations play a role in adrenal function in late gestation. Many studies have shown that the adrenal gland becomes more responsive to ACTH in late gestation, inasmuch as cortisol production in response to an acute increase in ACTH concentrations is greatly enhanced (Durand et al. 1981, 1982, Poore et al. 1998). The precise mechanisms controlling this increased responsiveness are not fully defined, but an increase in the number of ACTH receptors, or the efficiency of signal transduction, both in terms of second messenger production and the modulation of the steroidogenic process, have been suggested as possible means by which ACTH may become a more potent stimulus to cortisol production (Durand et al. 1981, 1982).

In the late-gestation ovine fetal adrenal gland, the mRNA concentration of a number of steroidogenic enzymes increases in a fashion that is somewhat parallel to the increase in fetal cortisol concentrations. These include the cholesterol side-chain cleavage enzyme $\left(\mathrm{P}_{450} \mathrm{scc}_{\mathrm{sc}}\right)$, $3 \beta$-hydroxysteroid dehydrogenase $/ \Delta^{4}-\Delta^{5}$ isomerase (3ßHSD), $17 \alpha$-hydroxylase $\left(\mathrm{P} 450_{\mathrm{C} 17}\right)$ and 21 -hydroxylase $\left(\mathrm{P}_{450}{ }_{\mathrm{C} 21}\right)$ (Phillips et al. 1996). Changes in the expression of the enzyme responsible for catalysing the final step of cortisol biosynthesis (11 $\beta$-hydroxylase) have not been demonstrated in the late-gestation ovine fetal adrenal gland, suggesting that this enzyme does not play an acute regulatory role in the increase in cortisol synthesis (Myers et al. 1992). In addition, the expression of $\mathrm{P} 450_{\mathrm{scc}}$ and $\mathrm{P} 450_{\mathrm{C} 17}$, but not $3 \beta \mathrm{HSD}$ nor $\mathrm{P} 450_{\mathrm{C} 21}$, is decreased after lesions of the hypothalamic paraventricular nucleus $(\mathrm{PVN})$, which destroy corticotrophin-releasing factorcontaining neurones, resulting in decreased cortisol concentrations and a failure of parturition in the ovine fetus (Myers et al. 1993). Likewise, hypothalamo-pituitary disconnection (HPD), which disrupts the humoral and neural connections between the hypothalamus and pituitary gland, and hypophysectomy, which results in low cortisol concentrations and failure of parturition, both also decrease the expression of $\mathrm{P} 450_{\mathrm{scc}}$ and $\mathrm{P} 450_{\mathrm{C} 17}$, as well as 3ßHSD (Phillips et al. 1996, Ross et al. 1997).

These intervention studies, PVN lesion and HPD, as well as the ontogenic studies have led to the hypothesis that diminished secretion of ACTH (and other pituitary factors) secretion leads to the decrease in adrenal steroidogenic enzyme expression (Myers et al. 1993, Phillips et al. 1996). Both surgical manipulations are, however, not completely specific, and the secretion of pituitary factors other than ACTH is also disrupted. While ACTH con- centrations increase in the late-gestation fetus, so do the concentrations of a number of other factors (prostaglandin $\mathrm{E}_{2}$, prolactin etc.) which may also play a role in the regulation of adrenal function (Deayton et al. 1994, Phillips et al. 1999). In the present study we have, therefore, directly examined the roles of ACTH, the pituitary gland and increasing gestational age in regulating the expression of adrenal steroidogenic enzymes. This was achieved by comparing the effects of an ACTH infusion at different gestational ages to intact fetuses, as well as examining the effect of the same infusion to fetuses with and without their pituitary glands. In addition to examining the expression of $\mathrm{P} 450_{\mathrm{scc}}, 3 \beta \mathrm{HSD}$ and $\mathrm{P} 450_{\mathrm{C} 17}$ we have also measured the relative abundance of the mRNA encoding the ACTH receptor (MC2R) and the transcription factor that plays a critical role in the regulation of the expression of a number of steroidogenic enzymes, steroidogenic factor 1 (SF-1) (Parker \& Schimmer 1997).

\section{Materials and Methods}

All experiments were conducted in accordance with the requirements of the Victorian Prevention of Cruelty to Animals Act 1986 and the Code of Practice for the Care and Use of Animals for Scientific Purposes of the National Health and Medical Research Council, and received prior approval from the Monash University Standing Committee on Ethics in Animal Experimentation.

\section{General methods}

Pregnant Border Leicester-Merino cross-bred ewes of known gestational age were used in these experiments. Ewes were housed in individual metabolism cages with a $12 \mathrm{~h}$ light: $12 \mathrm{~h}$ darkness cycle, fed once daily between 0900 and $1200 \mathrm{~h}$ and with water freely available. Surgery was performed between 113 days and 115 days of gestation using aseptic techniques. General anaesthesia was induced with thiopentone sodium in water $(20 \mathrm{mg} / \mathrm{kg}$; Pentothal, Bomac Laboratories Ltd, Asquith, NSW, Australia) and maintained by inhalation through an endotracheal tube with $0 \cdot 5-2 \cdot 0 \%$ halothane (Fluothane; ICI, Villawood, Australia) while vascular catheters were implanted into a fetal carotid artery and jugular vein.

The health of the fetuses was assessed by collecting a fetal arterial blood sample $(1 \mathrm{ml})$ every second day for the measurement of $\mathrm{PaO}_{2}, \mathrm{O}_{2}$ saturation, $\mathrm{PaCO}_{2}$ and haemoglobin concentration using an ABL5 blood gas analyser and an OSM2 haemoximeter (Radiometer, Copenhagen, Denmark).

At the end of each experiment the ewes were killed by an overdose of sodium pentobarbitone, and the fetal adrenal glands were rapidly dissected, weighed and immediately frozen in liquid nitrogen and stored at $-80{ }^{\circ} \mathrm{C}$. 
Experiment 1: The effect of ACTH infusion and labour in intact fetuses on the relative abundance of the $m R N A$ for $M C 2 R, S F-1, P 450_{s c o}, 3 \beta H S D$ and $P 450_{C 17}$

This experiment examined the hypothesis that a long-term continuous infusion of $\mathrm{ACTH}$ and labour regulate the expression of critical genes involved in fetal adrenal steroidogenesis. From the time of surgery, 20 fetuses received either an intravenous continuous infusion of saline $(1 \mathrm{ml} / \mathrm{h})$ or $\mathrm{ACTH}_{1-24}(14.7 \mathrm{pmol} / \mathrm{kg}$ per $\mathrm{h}$; Synacthen; Ciba Geigy Australia Ltd, Pendle Hill, NSW, Australia). Infusions were administered until either 132 days (intact (INT)/saline-treated (SAL) group, $n=4$; INT/ ACTH group, $n=5)$ or until the ewe was in established labour (INT/SAL, $n=6$; INT/ACTH, $n=5$ ) as determined by typical changes in the uterine electromyographic record (Harding et al. 1982). The dose of ACTH administered was increased every 5 days with estimated increases in fetal body weight (Cloete 1939). We have previously demonstrated that $\mathrm{ACTH}$ infusion at this dose to intact fetuses causes no increase in basal plasma cortisol concentrations, no enlargement of the adrenal glands and no advancement in the timing of labour. These fetuses, however, exhibited an enhanced cortisol response to the rapid intravenous administration of exogenous $\mathrm{ACTH}_{1-24}$ (Poore et al. 1998). ACTH $\mathrm{AC}_{1-24}$ was chosen as an experimental agent to mimic the actions of $\mathrm{ACTH}_{1-39}$, as the two appear to have equivalent potency at the MC2R (Kapas et al. 1996).

\section{ACTH challenge}

At 120 days of gestation all fetuses received $2.5 \mu \mathrm{g} / \mathrm{kg}$ $\mathrm{ACTH}_{1-24}$ by rapid intravenous injection. In addition, the animals receiving the $\mathrm{ACTH}_{1-24}$ infusion for 32 days also had challenge experiments performed at 130-131 days or 140-142 days of gestation. Fetal arterial blood samples $(2 \mathrm{ml})$ were collected for measurement of plasma cortisol concentrations at $30 \mathrm{~min}, 15 \mathrm{~min}$ and immediately prior to the ACTH injection (time 0 ) and at 10, 30, 60, 90 and $120 \mathrm{~min}$ after the ACTH challenge. This was performed to assess the effect of the continuous ACTH infusion on fetal adrenal responsiveness to the acute administration of ACTH. An additional fetal arterial blood sample $(2 \mathrm{ml})$ was collected for the measurement of fetal cortisol concentrations the day before the scheduled post-mortem or once labour was evident. At 132 days, or when labour was detected, the ewes were killed and the fetal adrenal glands collected as described above.

Experiment 2: The effect of ACTH infusion to intact and hypophysectomised fetuses on the relative abundance of the $m R N A$ for MC2R, SF-1, P450 sco $3 \beta H S D$ and $P 450_{C 17}$

This experiment examined the hypothesis that the expression of genes involved in fetal adrenal steroidogenesis is dependent on an intact pituitary gland and that a continuous ACTH infusion will restore any defect resulting from its removal. Surgery was performed on 18 pregnant ewes between 107 and 119 days of gestation (115 \pm 1 , mean \pm s.E.M.) and, in addition to the insertion of vascular catheters, as described above, seven fetuses also had their fetal pituitary gland removed (hypophysectomy, HX) as previously described (Mesiano et al. 1987). HX was carried out under direct vision and completeness was confirmed by inspection of the empty sella turcica both at the time of surgery and at post-mortem. Fetuses received an infusion of saline $(1 \mathrm{ml} / \mathrm{h}$ : INT/SAL, $n=6$; HX/SAL, $n=4)$ or $\mathrm{ACTH}_{1-24}(14.7 \mathrm{pmol} / \mathrm{kg}$ per $\mathrm{h}$ in $1 \mathrm{ml}$ heparinised saline: INT/ACTH, $n=5$; HX/ACTH, $n=3$ ) from the time of surgery until the detection of labour or until 155 days of gestation (for the HX/SAL fetuses). Infusion of this dose of $\mathrm{ACTH}_{1-24}$ results in normal cortisol profiles, adrenal morphology and enables labour to occur at the normal time in HX fetuses (Poore et al. 1998). The health of the fetuses was assessed by the measurement of fetal blood gases (see above); tests of adrenal responsiveness (see above) were conducted at 142 days of gestation and a fetal blood sample was collected on the day prior to post-mortem for the assessment of fetal cortisol concentrations. The experiment ended when labour was detected or at 155 days of gestation if labour did not occur. Note that intact fetuses receiving a saline or ACTH infusion are the same animals as the term animals described for experiment 1 .

\section{Cortisol radioimmunoassay}

Cortisol was extracted from fetal plasma with dichloromethane and the concentration of cortisol was measured by radioimmunoassay as previously described (Bocking et al. 1986). Intra- and interassay coefficients were 5 and $18 \%$ respectively. The sensitivity of the assay was $1 \cdot 2 \pm 0 \cdot 3 \mathrm{ng} / \mathrm{ml}$.

\section{Total RNA extraction from fetal adrenal glands}

Frozen fetal adrenal glands were weighed and then homogenised in Tri-Reagent ${ }^{(\mathbb{M})}$ (Sigma, Castle Hill, NSW, Australia) and total RNA was isolated as described in the manufacturer's instructions. The concentration of nucleic acids was quantified by spectrophotometry (UV/VIS 918; GBC Scientific Equipment PTY Ltd, Dandenong, Victoria, Australia) at a wavelength of $260 \mathrm{~nm}$. Ratios of $260 / 280 \mathrm{~nm}$ were used to determine the purity of the total RNA.

\section{Probes}

cDNA encoding bovine MC2R was generously provided by Dr K Mountjoy (University of Auckland, Auckland, New Zealand; Mountjoy et al. 1992). The human P450 scc 
(Chung et al. 1986) and $\mathrm{P} 450_{\mathrm{C} 17}$ (Chung et al. 1987) cDNA probes were kindly provided by Professor W Miller (University of California at San Francisco, San Francisco, CA, USA). The human cDNA probe for $3 \beta \mathrm{HSD}$ (Lorence et al. 1990) was generously donated by Dr R Rodgers (Flinders University of South Australia, Bedford Park, Australia). Dr K Morohashi (Kyushu University, Fukuoka, Japan) kindly provided the cDNA probe for SF-1 (Ad4 BP; Honda et al. 1993). A cDNA probe for rat 18S rRNA was used. cDNA probes were random prime labelled with $\alpha-\left[{ }^{32} \mathrm{P}\right] \mathrm{dCTP} \quad(3000 \mathrm{Ci} / \mathrm{mmol}$; New England Nuclear, Boston, MA, USA; Oligolabelling kit; Pharmacia Biotech, Stockholm, Sweden) to the specific activity of $1 \times 10^{9}$ c.p.m. $/ \mu \mathrm{g}$ DNA.

The bovine MC2R probes shows 96\% nucleotide identity to the ovine MC2R mRNA sequence within the coding region, the human $\mathrm{P} 450_{\mathrm{scc}}$ probe shows $82 \%$ nucleotide identity to the ovine $\mathrm{P} 450_{\mathrm{scc}} \mathrm{mRNA}$ within the coding region, and the human $\mathrm{P}_{4} 50_{\mathrm{C} 17}$ probe has $80 \%$ identity to the ovine $\mathrm{P} 450_{\mathrm{C} 17}$ mRNA within the coding region. Nucleotide sequences for the ovine $3 \beta \mathrm{HSD}$ and SF-1 mRNAs are unknown. The identities of nucleotide sequences were determined using BLAST 2 sequences software (http://www.ncbi.nlm.nih.gov/gorf/ wblast2.cgi).

\section{Analysis of $m R N A$ abundance}

Northern blot analysis Adrenal gland total RNA (20 $\mu \mathrm{g} / \mathrm{sample})$ was denatured by incubation in formaldehyde $(2 \cdot 2 \mathrm{M})$ and $50 \%(\mathrm{v} / \mathrm{v})$ formamide at $55^{\circ} \mathrm{C}$ for $15 \mathrm{~min}$ and then separated by electrophoresis in a $1 \%$ agarose gel containing $2 \cdot 2 \mathrm{M}$ formaldehyde. Capillary blotting was used to transfer the RNA to Duralon nylon membrane (Stratagene, La Jolla, CA, USA).

Slot blot analysis Adrenal gland total RNA was applied to Duralon membrane using a slot blot apparatus (Hoeffer Scientific, San Francisco, CA, USA) (Phillips et al. 1996). In brief, total RNA from fetal adrenal glands $(10 \mu \mathrm{g} / \mathrm{slot})$ or wether adrenal glands $(2 \cdot 5-10 \mu \mathrm{g} / \mathrm{slot})$ was denatured with $6.15 \mathrm{M}$ formaldehyde and $10 \times \mathrm{SSC}$ at $55^{\circ} \mathrm{C}$ for $15 \mathrm{~min}$, and then applied to the nylon membrane. Membranes from Northern and slot blots were air dried and the RNA fixed to the membrane by baking at $80{ }^{\circ} \mathrm{C}$ for $1 \mathrm{~h}$ or by exposure to UV light $\left(0 \cdot 12 \mathrm{~J} / \mathrm{cm}^{2}\right)$ for $30 \mathrm{~s}$ in a UV crosslinker (UVC 500; Hoeffer, San Francisco, CA, USA). The membranes were then incubated in hybridisation buffer $(7 \%(\mathrm{w} / \mathrm{v})$ SDS, $50 \%(\mathrm{v} / \mathrm{v})$ deionised formamide, $5 \times \operatorname{SSPE}(50 \mathrm{mM}$ sodium phosphate dibasic, $0.75 \mathrm{M}$ sodium chloride, $5 \mathrm{mM}$ EDTA and $100 \mu \mathrm{g} / \mathrm{ml}$ denatured salmon sperm DNA)) at $42{ }^{\circ} \mathrm{C}$ for $6 \mathrm{~h}$, followed by an incubation with the relevant cDNA probe $\left(1-2 \times 10^{6}\right.$ c.p.m./ml) in hybridisation buffer for $16 \mathrm{~h}$ at $42{ }^{\circ} \mathrm{C}$. The membranes were then subjected to a series of $30-\mathrm{min}$ washes (once in $1 \times \mathrm{SSC}, 0 \cdot 1 \% \mathrm{SDS}$ at room temperature, then twice in $0 \cdot 1 \times \mathrm{SSC}, 0 \cdot 1 \% \mathrm{SDS}$ at $42{ }^{\circ} \mathrm{C}$ ). Finally, the membranes were air-dried and placed in an X-ray film cassette containing a storage phosphor screen (Kodak) for $16 \mathrm{~h}$. The image was then visualised and signals quantified using ImageQuaNT (Molecular Dynamics, Sunnyvale, CA, USA). Membranes were stripped of cDNA probes in between hybridisations by washing in $0.01 \times$ SSC, $0.5 \%$ SDS for $15 \mathrm{~min}$ at $90{ }^{\circ} \mathrm{C}$. Even Northern and slot loading was verified by a final hybridisation with $18 \mathrm{~S}$ rRNA cDNA probe.

\section{Data analysis}

Prior to analysis, the abundance of an individual mRNA as determined by densitometry was calculated as a ratio of the amount of $18 \mathrm{~S}$ rRNA in the same sample. The responsiveness of the fetal adrenal gland as tested by the ACTH challenge was measured by integrating the plasma cortisol response to ACTH (time points $10-120 \mathrm{~min}$ ) above the mean preinjection cortisol concentrations ( -30 to $0 \mathrm{~min}$ ). All data were analysed by ANOVA (SPSS for Windows (version 8)) following the assessment of homogeneity of variances using Levene's test. Where appropriate, data were square root or log-transformed prior to analysis. For experiments 1 and 2 the results were compared using two-factor ANOVA (experiment 1 main effects: ACTH infusion and gestational age; experiment 2 main effects: HX and ACTH infusion). When statistically significant interactions between main factors occurred, differences between individual mean values were detected using Fisher's least significant difference test. The data from experiments 1 and 2 were also pooled and compared with the immediate premortem cortisol concentrations using regression analysis in the SPSS package. All results are presented as means \pm S.E.M. and a probability level of $5 \%$ was considered significant.

\section{Results}

\section{Fetal well being}

All fetuses were considered healthy at the time of elective post-mortem. Immediately prior to euthanasia, the fetuses had haemoglobin values of $8.75 \pm 2.5 \mathrm{~g} / \mathrm{dl}, \mathrm{pH}$ values of $7 \cdot 40 \pm 0.02$ and $\mathrm{PaO}_{2}$ values of $18.5 \pm 3.5 \mathrm{mmHg}$.

\section{$m R N A$ transcript size}

The bovine MC2R cDNA probe hybridised with a transcript at $4 \cdot 0 \mathrm{~kb}$, bovine SF-1 cDNA probe hybridised with two transcripts of 3.0 and $4.0 \mathrm{~kb}$, human $\mathrm{P} 450_{\mathrm{scc}}$ cDNA bound with a single transcript of size $1.9 \mathrm{~kb}$, human 33HSD cDNA hybridised with a single transcript of $1.6 \mathrm{~kb}$, while human $\mathrm{P} 450_{\mathrm{C} 17}$ cDNA bound to a transcript of $1.7 \mathrm{~kb}$. $18 \mathrm{~S}$ rRNA cDNA probe hybridised to 
a transcript at $2 \cdot 0 \mathrm{~kb}$. The sizes of these mRNA transcripts in the ovine fetal adrenal gland correspond in size to their human, rat or bovine counterparts (data not shown). There were no differences in the mean levels of $18 \mathrm{~S}$ rRNA, measured in densitometric units between any of the treatment groups.

Experiment 1: The effect of ACTH infusion and labour in intact fetuses on the relative abundance of the $m R N A$ for $M C 2 R, S F-1, P 450_{s c o}, 3 \beta H S D$ and $P 450_{C 17}$

The $\mathrm{ACTH}_{1-24}$ infusion had no significant effect on the fetal adrenal to body weight ratio at either gestational age, though there was a significant $(P<0 \cdot 05)$ increase in this ratio between 132 days of gestation and term (data not shown). Consistent with our previous report (Poore et al. 1998), the $\mathrm{ACTH}_{1-24}$ infusion increased $(P<0 \cdot 05)$ the cortisol response to a challenge with ACTH in the fetuses killed at 132 days of gestation (INT/SAL $187 \pm 81$ vs INT/ACTH $1891 \pm 459 \mathrm{ng} / \mathrm{min}$ per $\mathrm{ml}$ ).

Neither the ACTH infusion nor labour had a significant effect on the relative abundance of the mRNAs for SF-1 and MC2R (Fig. 1). ACTH A $_{14}$ infusion significantly increased the abundance of the mRNA for $\mathrm{P} 450_{\mathrm{scc}}$ and $3 \beta \mathrm{HSD}$ in the adrenal glands of 132 days of gestation fetuses, but was without effect in fetuses at the time of labour. Fetuses of ewes in labour, however, had a significantly greater abundance of mRNA for $\mathrm{P} 450 \mathrm{scc}_{\mathrm{sc}}$ and $3 \beta H S D$ than either group of fetuses at 132 days of gestation (Fig. 1). The ACTH infusion did not affect the abundance of the mRNA for $\mathrm{P} 450_{\mathrm{C} 17}$ at either 132 days or in labour, but the expression of the mRNA was greater in both groups of animals at labour (Fig. 1).

Experiment 2: The effect of ACTH infusion to intact and $H X$ fetuses on the relative abundance of the $m R N A$ for $M C 2 R, S F-1, P 450_{s c}, 3 \beta H S D$ and $P 450_{C 17}$

The fetal adrenal to body weight ratio was significantly $(P<0.05)$ decreased in the HX/SAL fetuses, while ACTH infusion restored the ratio to that seen in intact fetuses (Poore et al. 1998, data not shown). HX/SAL fetuses failed to generate a significant cortisol response to the ACTH challenge (data not shown).

The relative abundance of the mRNA for MC2R was unaffected by ACTH infusion or HX (Fig. 2). Following removal of the fetal pituitary gland there was a significant decrease in the abundance of the mRNA for SF-1, although ACTH infusion was without effect on the expression of this mRNA (Fig. 2). The abundance of mRNAs for both $\mathrm{P} 450_{\mathrm{scc}}$ and $3 \beta \mathrm{HSD}$ decreased following HX. ACTH infusion restored the abundance of these mRNAs to values not different from that seen in intact fetuses; however, the infusion was without effect in intact animals (Fig. 2). The expression of the mRNA for $\mathrm{P}^{4} 0_{\mathrm{C} 17}$ was significantly decreased in the $\mathrm{HX} / \mathrm{SAL}$ group when compared with the INT/SAL animals. ACTH infusion to HX animals restored the amount of mRNA to values seen in the INT/SAL group. In contrast, the ACTH infusion to intact animals significantly decreased the amount of mRNA encoding $\mathrm{P} 450_{\mathrm{C} 17}$, although the values in this group were not different from the HX/ACTH animals (Fig. 2). This effect of ACTH on $\mathrm{P}^{4} 0_{\mathrm{C} 17} \mathrm{mRNA}$ content in intact animals may be of limited physiological significance, as analysis of the same data in experiment 1 did not identify a significant effect.

The relationship between plasma cortisol concentration and the abundance of the $m R N A$ encoding $M C 2 R, S F-1, P 450_{s c c}$ $3 \beta H S D$ and $P 450_{C 17}$

For each animal in experiments 1 and 2, the individual cortisol concentrations obtained on the day before death or labour were correlated with the relative expression of each of the mRNAs measured (Fig. 3). Cortisol concentrations were not significantly correlated with the expression of mRNAs encoding MC2R (Pearson correlation coefficient, $r=0.025)$ or SF-1 $(r=0.038)$. There were highly significantly correlations between the plasma cortisol concentrations and the mRNAs encoding $\mathrm{P} 40_{\mathrm{scc}}(r=0.854)$, $3 \beta \mathrm{HSD} \quad(r=0.811)$ and $\mathrm{P} 40_{\mathrm{C} 17} \quad(r=0.58) \quad$ (Fig. 3). Multiple linear regression failed to significantly improve the relationship between the relative abundance of the mRNA for the steroidogenic enzymes and premortem cortisol concentrations. This was due, at least in part, to significant correlations between the individual enzymes $\left(\mathrm{P} 450_{\mathrm{scc}}\right.$ vs $3 \beta \mathrm{HSD}, r=0 \cdot 90$; $\mathrm{P}_{450}$ scc $v \mathrm{P} 450_{\mathrm{C} 17}, r=0 \cdot 76$; $3 \beta \mathrm{HSD}$ vs $\left.\mathrm{P} 450_{\mathrm{C} 17}, r=0.64\right)$.

\section{Discussion}

The results reported in this paper suggest a complex regulation of the abundance of a number of mRNA transcripts encoding proteins that are important for the control of steroidogenesis in the adrenal gland of the late-gestation fetal sheep. Our experimental approaches allow us to begin to dissect the relative contributions of $\mathrm{ACTH}$, the pituitary gland and advancing gestational age in the maturation of adrenal cortical function. The results we have obtained suggest that changes in the expression of genes encoding the steroidogenic enzymes are likely to be important in increasing the synthetic capacity of the adrenal gland. Their regulation, however, does not appear to be under the exclusive control of $\mathrm{ACTH}$, further emphasising the complex regulation of adrenal maturation at this stage of fetal life.

We have previously shown that the infusion of $\mathrm{ACTH}_{1-24}(14.7 \mathrm{pmol} / \mathrm{kg}$ per h) to HX fetuses restores immunoreactive (ir)-ACTH concentrations to values seen in intact animals. Furthermore, when intact animals receive the $\mathrm{ACTH}_{1-24}$ infusion there is no increase in 

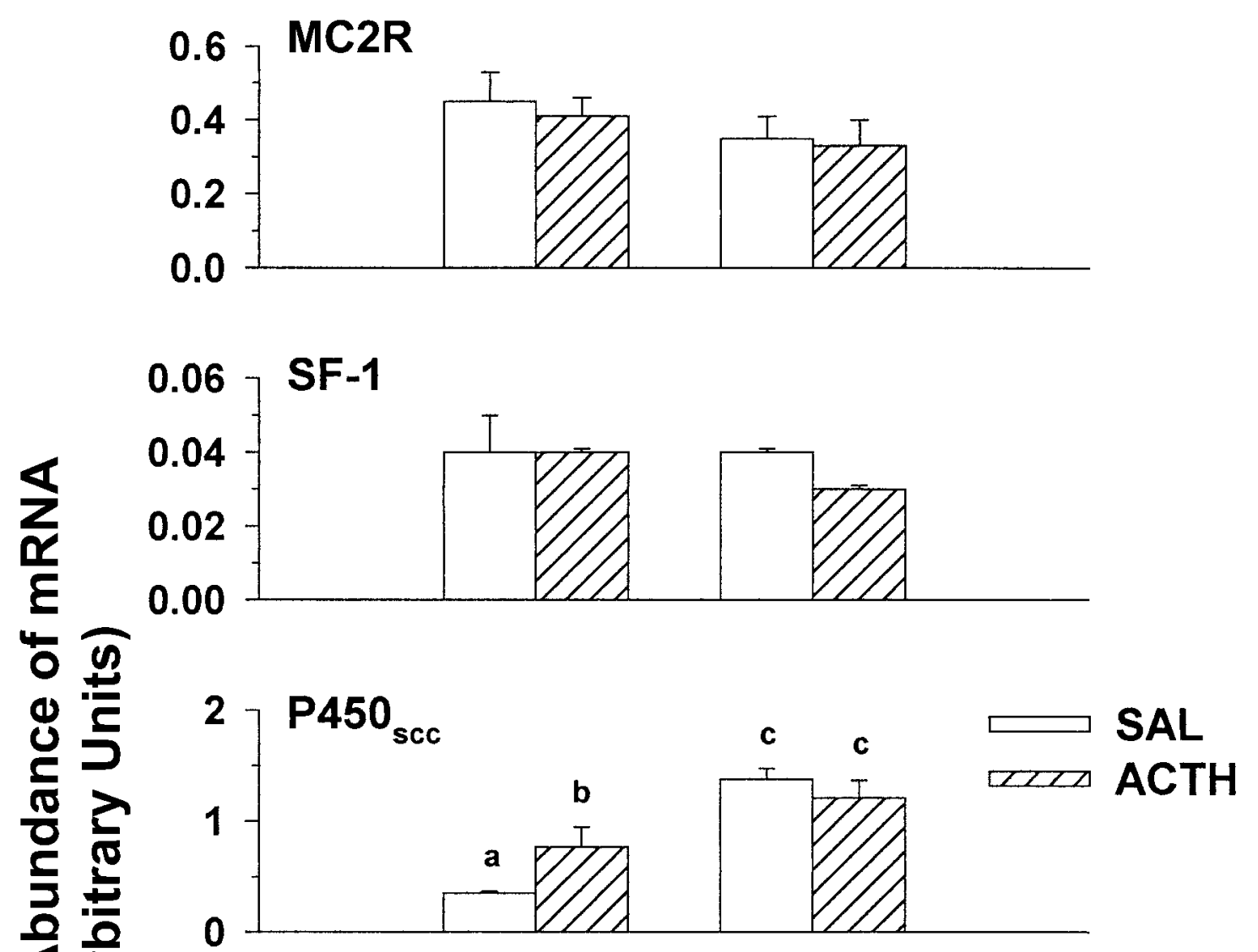

$\frac{1}{0} \leq$
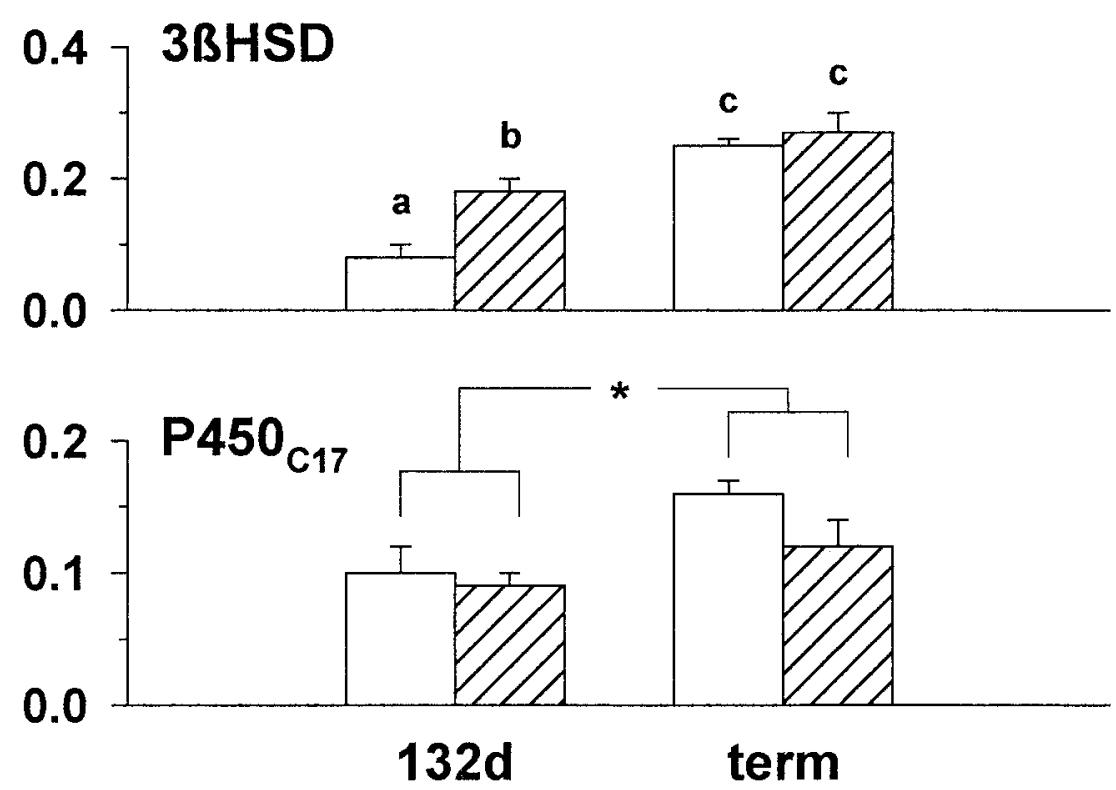

Figure 1 Effect of $\mathrm{ACTH}_{1-24}$ infusion to intact fetal sheep on the relative abundance of the mRNA encoding MC2R, SF-1, $\mathrm{P} 450_{\mathrm{scC}} 3 \beta \mathrm{HSD}$ and $\mathrm{P} 450_{\mathrm{C} 17}$ in adrenals from either saline- or $\mathrm{ACTH} \mathrm{H}_{1-24}$-infused fetuses at either 132 days of gestation (132d) (INT/SAL, $n=4$; INT/ACTH, $n=5$ ) or at term (INT/SAL, $n=6$; INT/ACTH, $n=5$ ). Different letters indicate groups that are significantly different from each other; asterisk indicates significant difference between the 132-day and term groups. 

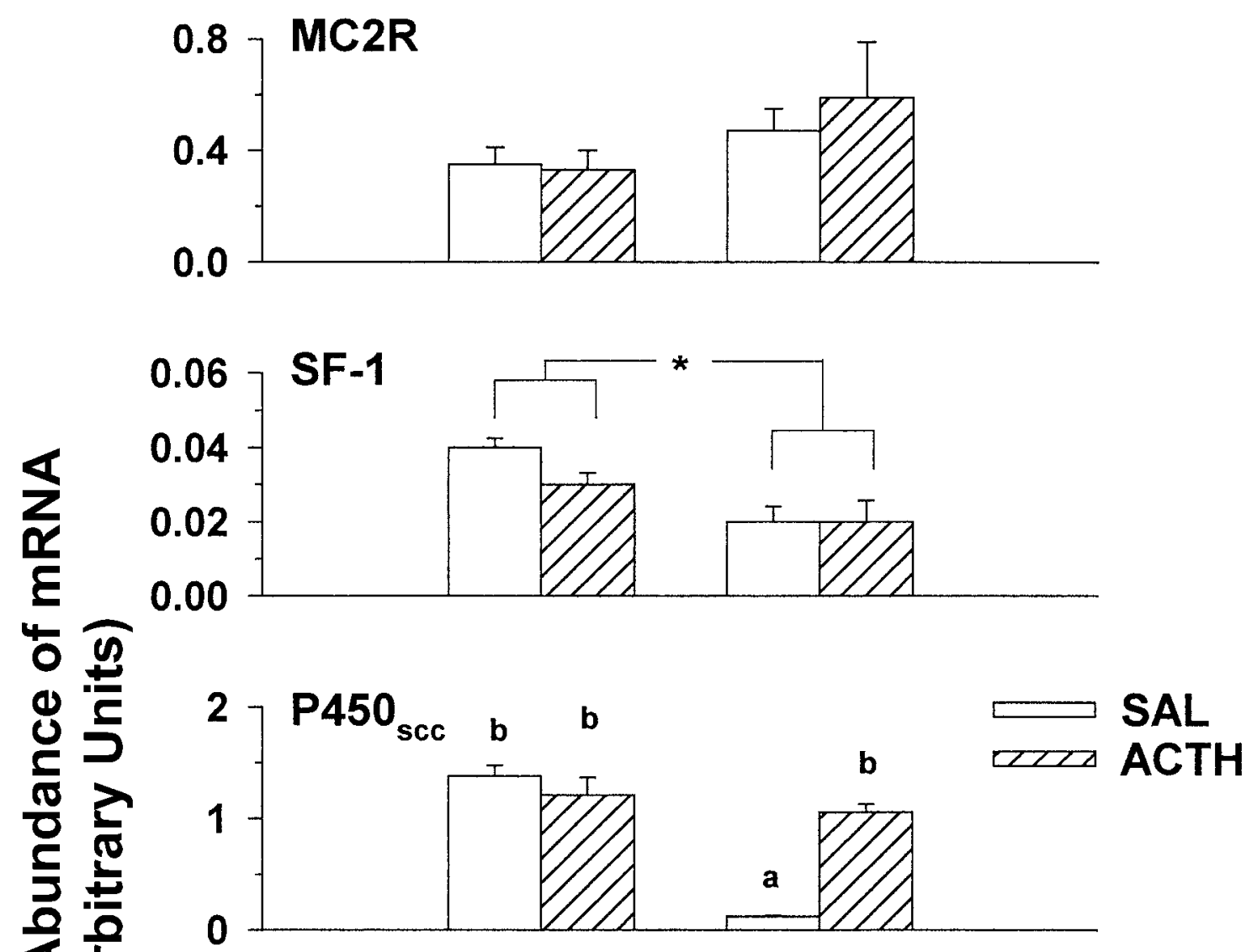

$\frac{1}{0}$
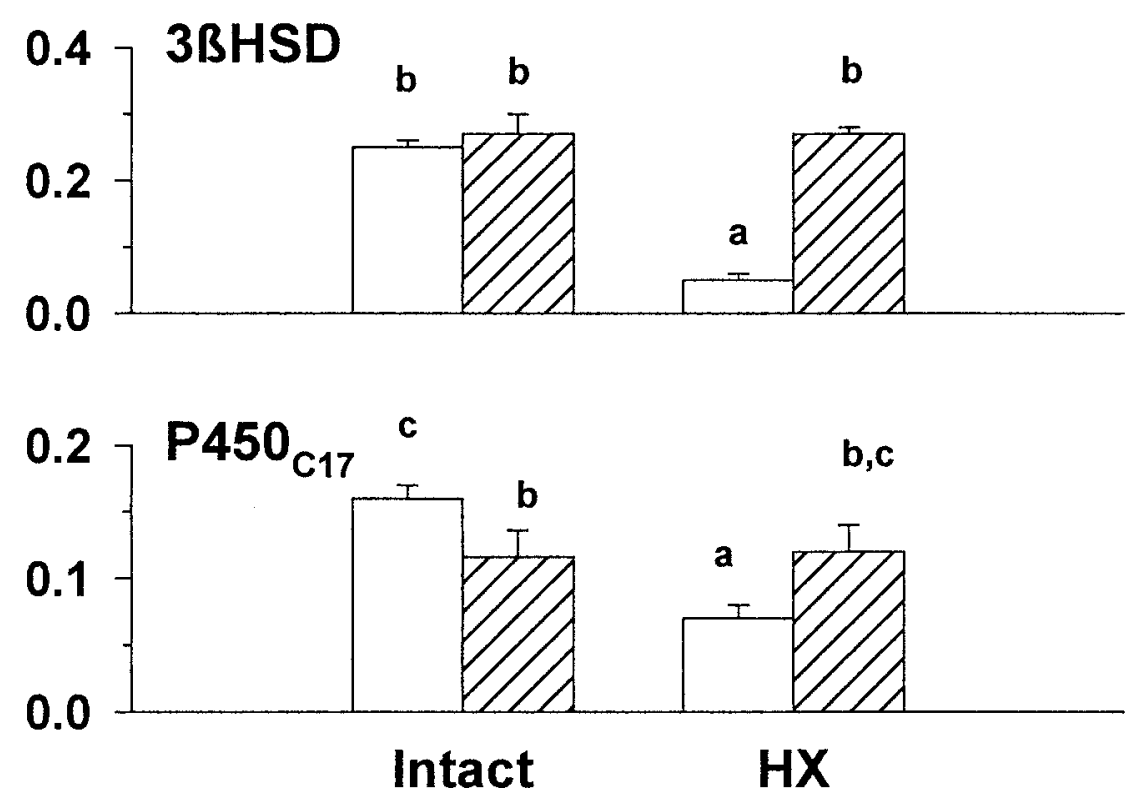

Figure 2 The expression of the mRNA encoding MC2R, SF-1, $\mathrm{P} 450_{\mathrm{SCC}} 3 \mathrm{BHSD}$ and $\mathrm{P}_{450} \mathrm{C}_{\mathrm{C} 17}$ in adrenals from intact or $\mathrm{HX}$ fetal sheep at term (or 155 days; HX/SAL group, $n=4$ ). Fetuses received either saline or $\mathrm{ACTH}_{1-24}$ infusions (INT/SAL, $n=6$; INT/ACTH, $n=5 ; \mathrm{HX} / \mathrm{ACTH}, n=3$ ). Different letters indicate groups that are significantly different from each other; asterisk indicates significant difference between the intact and $\mathrm{HX}$ groups. 

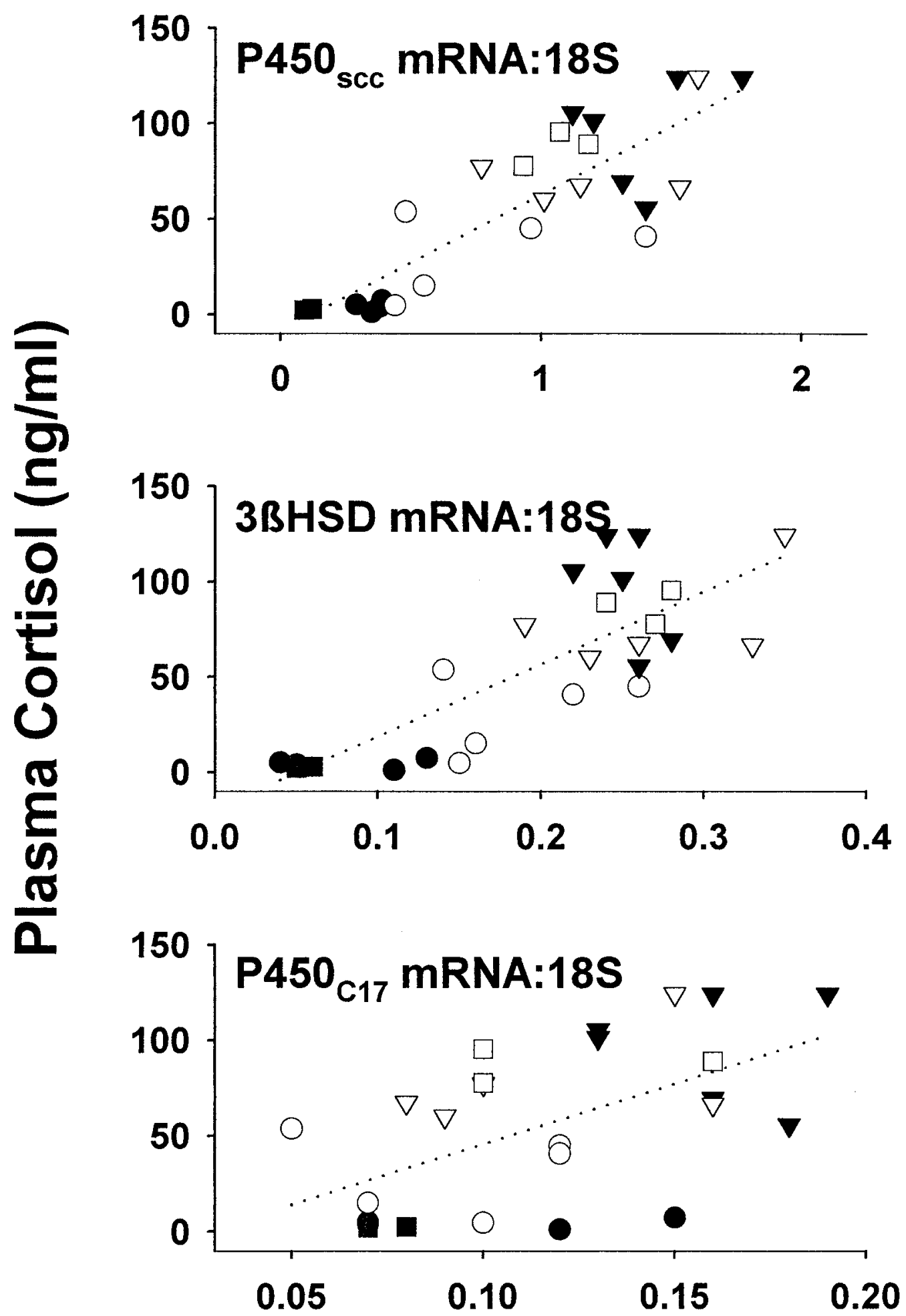

Figure 3 The relationship between premortem plasma cortisol concentration and the abundance of the mRNA encoding $\mathrm{P}_{450} \mathrm{scC}_{\mathrm{sC}} 3 \beta \mathrm{HSD}$ and $\mathrm{P} 450_{\mathrm{C} 17}$ in fetal adrenal glands. INT/SAL at 132 days of gestation (-); INT/ACTH at 132 days of gestation $(\bigcirc)$; INT/SAL at term $(\boldsymbol{\nabla})$; INT/ACTH at term $(\nabla)$; HX/SAL at 155 days of gestation ( $\mathbf{\square})$; HX/ACTH at term ( $\square$ ). Cortisol concentrations were significantly correlated with $\mathrm{P}^{4} 50_{\mathrm{scc}}(r=0 \cdot 85), 3 \beta \mathrm{HSD}$ $(r=0 \cdot 81)$ and $\mathrm{P} 40_{\mathrm{C} 17}(r=0 \cdot 58)$. 
ir-ACTH concentrations when compared with intact fetuses receiving saline (Poore et al. 1998). In addition, the concentrations of ir-ACTH were not significantly different in the intact fetuses receiving $\mathrm{ACTH}_{1-24}$ or saline for 18 days to 132 days (data not shown). The similarity of $\mathrm{ACTH}$ and cortisol profiles between intact fetuses with saline or $\mathrm{ACTH}_{1-24}$ and $\mathrm{HX}$ fetuses infused with $\mathrm{ACTH}_{1-24}$ indicates that the biological response to exogenous ACTH was not adversely influenced by the constant mode of infusion of $\mathrm{ACTH}_{1-24}$ used in these studies. There is some evidence that endogenous secretion of ACTH may have been slightly reduced in intact fetuses receiving the $\mathrm{ACTH}_{1-24}$ infusion but the occurrence of a prepartum ir-ACTH and cortisol increase in these fetuses indicates that the $\mathrm{ACTH}_{1-24}$ infusion was not associated with a severe depression of HPA activity (Poore et al. 1998). It is formally possible that if the endogenous secretion of $\mathrm{ACTH}_{1-39}$ is decreased in intact fetuses receiving the $\mathrm{ACTH}_{1-24}$ infusion, then the secretion of other pro-opiomelanocortin (POMC)-derived products from the pituitary will also be decreased. These compounds may affect the development of the fetal adrenal gland and the expression of adrenal steroidogenic enzymes (Estivariz et al. 1982), but definitive studies concerning this issue have not been undertaken. Notwithstanding, the constant infusion of the dose of $\mathrm{ACTH}_{1-24}$ employed in the current study appears to be without profound effect on the basal activity of the ovine fetal HPA axis.

These results clearly demonstrate that the pituitary gland and ACTH positively regulate the expression in the adrenal gland of three of the enzymes involved in cortisol biosynthesis. The effects of the $\mathrm{ACTH}_{1-24}$ infusion, and labour, on the abundance of the mRNA for $\mathrm{P} 450_{\mathrm{scc}}$ and $3 \beta \mathrm{HSD}$ were similar. When $\mathrm{ACTH}_{1-24}$ was infused into intact animals for 18 days until 132 days of gestation (approximately 2 weeks prior to normal delivery) there was a significant increase in levels of both mRNAs. This increase was not maximal since, by the time of labour, further significant increases in mRNA abundance had occurred. At term, the $\mathrm{ACTH}_{1-24}$ infusion was without any additional effect on the expression of mRNA for $\mathrm{P} 450_{\mathrm{scc}}$ or $3 \beta \mathrm{HSD}$. It is not clear whether this lack of additional effect reflects the fact that steady-state mRNA levels had reached a maximum by the time of labour in the intact animals, if ACTH secretion was at a maximum in the saline-infused animals at this time, or if factors in addition to ACTH influence the expression of these enzymes by term. Hypophysectomy, on the other hand, dramatically reduced the expression of both enzymes, an effect which was completely restored by the $\mathrm{ACTH}_{1-24}$ infusion. This observation confirms the critical role of pituitary-derived ACTH in regulating the expression of $\mathrm{P}_{450} \mathrm{scc}_{\mathrm{s}}$ and $3 \beta \mathrm{HSD}$.

The observations for $\mathrm{P}^{4} 50_{\mathrm{C} 17}$ were somewhat more complex. When given to intact animals, the $\mathrm{ACTH}_{1-24}$ infusion appeared to be generally without effect on the abundance of the mRNA, irrespective of whether the infusion had been given for 18 or 32 days. In intact animals, however, there was a significant increase in the abundance of the mRNA between 132 days and term. Conversely, hypophysectomy caused an approximately $50 \%$ reduction in the expression of $\mathrm{P} 40_{\mathrm{C} 17}$, and $\mathrm{ACTH}_{1-24}$ infusion restored the abundance to levels not different from those of intact fetuses at term. These observations suggest that while ACTH plays a critical role in regulating the expression of $\mathrm{P}_{450} \mathrm{C}_{17}$, other factors may be necessary to explain the increase in expression that is seen with advancing gestational age.

Taken together, these findings confirm and extend previous observations regarding the ontogeny and regulation of steroidogenic enzymes in the late-gestation sheep fetus. As the present study included animals that were confirmed to be in established labour, we have been able to demonstrate that the expression of $3 \beta \mathrm{HSD}$ increases with advancing gestational age, an observation at odds with a previous report (Phillips et al. 1996). This difference may be accounted for by the facts that our earlier study did not include animals in labour and that the capacity of the fetal adrenal to secrete cortisol increases dramatically in the last $48 \mathrm{~h}$ of fetal life. Our finding of increased expression of the mRNA encoding $3 \beta \mathrm{HSD}$ in the present study is not unexpected, given the dramatic increase in cortisol production that is seen over the last 2 weeks of gestation, and our previous observation that HPD decreased the expression of the enzyme. Furthermore, it is consistent with observations made for $\mathrm{P} 450_{\mathrm{scc}}$ and $\mathrm{P} 450_{\mathrm{C} 17}$. The effects of hypophysectomy were remarkably similar to those we have previously reported for the HPD procedure (Phillips et al. 1996, Ross et al. 1997). By infusing $\mathrm{ACTH}_{1-24}$ to HX fetuses, at a rate sufficient to restore basal cortisol concentrations and maintain the correct timing of labour, we have been able to directly confirm the pivotal role played by ACTH in regulating the expression of $\mathrm{P}^{4} 50_{\mathrm{scc}}$, $3 \beta \mathrm{HSD}$ and $\mathrm{P} 450_{\mathrm{C} 17}$ mRNA. This is an important finding, as previous studies that have employed the use of the HPD procedure or bilateral hypothalamic PVN lesions may have induced a range of effects on pituitary hormone secretion, which are not necessarily restricted to the HPA axis.

Neither surgical manipulations nor ACTH infusion nor advancing gestational age had an effect on the abundance of the mRNA for MC2R. This was a somewhat surprising finding given previous reports that have suggested that the expression of MC2R mRNA in ovine adrenocortical cells is regulated by ACTH and glucocorticoids (Picard-Hagen et al. 1997), and that ACTH binding and the efficiency of ACTH signal transduction increases with advancing gestational age in the ovine fetal adrenal (Durand et al. 1981, 1982). Our Northern blot analysis revealed a single transcript of approximately $4 \mathrm{~kb}$, whereas other reports, using the same probe as that used in this study, have suggested multiple transcripts of $1 \cdot 3,1 \cdot 8,3 \cdot 6$ and $4 \cdot 2 \mathrm{~kb}$ in 
adult ovine adrenocortical cells (Picard-Hagen et al. 1997). If multiple transcripts also exist in the ovine fetal adrenal, and their abundance was below the detection limit for our initial Northern blot analysis, it is possible that any changes in their expression induced by our experimental procedures may have been obscured by the contribution of other transcripts when analysed by slot blot techniques. In addition, we extracted total RNA from both the cortex and medulla of the fetal adrenal gland, and again this approach may have obscured significant changes occurring only in the relevant cells of the cortex.

The expression of SF-1 was also not affected by $\mathrm{ACTH}_{1-24}$ infusion or advancing gestational age. Fetal hypophysectomy reduced SF-1 mRNA levels by approximately $50 \%$ and $\mathrm{ACTH}_{1-24}$ infusion was without any effect in HX fetuses. This suggests that SF-1 levels are controlled, at least in part, by a pituitary-derived factor, distinct from ACTH. There are a number of candidate pituitary molecules that have been implicated in adrenal development, including a number of fragments of the POMC molecule and prolactin (Estivariz et al. 1982, Phillips et al. 1999). Whether any one of these has a role in the regulation of SF-1 levels is a matter of speculation. Furthermore, the physiological effects of such a modest reduction in SF-1 mRNA levels, in terms of actual protein levels, is unclear.

As the production of cortisol is an important function of the ovine fetal adrenal gland, we correlated the abundance of each mRNA in individual adrenal glands with the plasma cortisol concentrations in that animal on the day before tissue collection. Not surprisingly, no significant relationship between the mRNA for SF-1 or MC2R and cortisol concentrations was observed; however, highly significant correlations between the three steroidogenic enzymes and cortisol were seen. In the case of $\mathrm{P} 450_{\mathrm{scc}}$ and $3 \beta \mathrm{HSD}$ the $r$ values were in excess of $0 \cdot 81$, suggesting that the expression of these enzymes plays a critical role in determining cortisol concentrations. The correlation between $\mathrm{P} 450_{\mathrm{C} 17}$ and cortisol was not as strong, although it was still highly statistically significant. Multiple regression analysis did not reveal any significant increase in the predictive value for the mRNA levels on cortisol concentrations, suggesting that the expression of the mRNA for the steroidogenic enzymes is somewhat interrelated. This is not surprising, given the parallel findings we observed in response to our experimental manoeuvres.

In conclusion, the results of the present study confirm the critical role of the pituitary gland and ACTH in regulating the function of the ovine fetal adrenal gland. The expression of mRNA encoding proteins critical in the steroidogenic pathway was clearly affected by our experimental manipulations, while the expression of $\mathrm{MC} 2 \mathrm{R}$ and SF-1 was largely unaffected. ACTH did not appear, however, to be the only factor involved in regulating the steroidogenic enzymes as, in a number of cases, $\mathrm{ACTH}_{1-24}$ infusion was unable to increase enzyme expression in intact animals, or fully restore the effects of hypophysectomy. Despite the fact that ACTH did not fully restore the effects of hypophysectomy on $\mathrm{P}^{4} 50_{\mathrm{C} 17}$ expression, these animals had normal cortisol concentrations and precipitated labour at the appropriate time. These observations are consistent with our previous suggestions that $\mathrm{ACTH}$ plays an essential, but largely permissive, role in the regulation of cortisol secretion in the late-gestation ovine fetus, with the potential for the involvement of other factors. The identity of these factors awaits elucidation.

\section{Acknowledgements}

We would like to acknowledge the expert technical assistance provided by $\mathrm{Mr}$ Alex Satragno and Ms Jan Loose. This work was funded, in part, by the National Health and Medical Research Council of Australia and the Australian Research Council.

\section{References}

Antolovich GC, McMillen IC, Robinson PM, Silver M, Young IR \& Perry RA 1991 The effect of hypothalamo-pituitary disconnection on the functional and morphologic development of the pituitaryadrenal axis in the fetal sheep in the last third of gestation. Neuroendocrinology 54 254-261.

Bocking AD, McMillen IC, Harding R \& Thorburn GD 1986 Effect of reduced uterine blood flow on fetal and maternal cortisol. Journal of Developmental Physiology 8 237-245.

Canny BJ, Young IR \& Veldhuis JD 1998 Hypothalamo-pituitary disconnection of the late-gestation ovine fetus results in profound changes in cortisol secretion that are not reflected in commensurate changes in adrenocorticotropin secretion. Endocrinology 139 3210-3219.

Chung B-C, Matteson KJ, Voutilainen R, Mohandas TK \& Miller WL 1986 Human cholesterol side chain cleavage enzyme, P450 scc: cDNA cloning, assignment of the gene to chromosome 15, and expression in the placenta. PNAS 83 8962-8966.

Chung B-C, Picado-Leonard J, Haniu M, Bienkowski M, Hall PF, Shively JE \& Miller WL 1987 Cytochrome P450C17 (steroid $17 \alpha$-hydroxylase/17,20 lyase): cloning of human adrenal and testis cDNAs indicates the same gene is expressed in both tissues. PNAS 84 407-411.

Cloete JHL 1939 Prenatal growth in the Merino sheep. Onderstepoort Journal of Veterinary Science and Animal Industry 13 417-558.

Deayton JM, Young IR, Hollingworth SA, White A, Crosby SR \& Thorburn GD 1994 Effect of late hypothalamo-pituitary disconnection on the development of the HPA axis in the ovine fetus and the initiation of parturition. Journal of Neuroendocrinology 6 $25-31$.

Drost M \& Holm LW 1968 Prolonged gestation in ewes after foetal adrenalectomy. Journal of Endocrinology 40 293-296.

Durand P, Cathiard AM, Morera AM, Dazord A \& Saez JM 1981 Maturation of adrenocorticotropin-sensitive adenylate cyclase of ovine fetal adrenal during late pregnancy. Endocrinology 108 2114-2119

Durand P, Cathiard AM, Locatelli A \& Saez JM 1982 Modifications of the steroidogenic pathway during spontaneous and adrenocorticotropin-induced maturation of ovine fetal adrenal. Endocrinology 110 500-505.

Estivariz FE, Iturriza F, McLean C, Hope J \& Lowry PJ 1982 Stimulation of adrenal mitogenesis by N-terminal proopiocortin peptides. Nature 297 419-422. 
Harding R, Poore ER, Bailey A, Thorburn GD, Jansen CAM \& Nathanielsz PW 1982 Electromyographic activity of the non-pregnant and pregnant sheep uterus. American Journal of Obstetrics and Gynecology 142 448-457.

Honda S-I, Morohashi K-I, Nomura M, Takeya H, Kitajima M \& Omura T 1993 Ad4 BP regulating steroidogenic P-450 gene is a member of steroid hormone receptor superfamily. Journal of Biological Chemistry 268 7494-7502.

Kapas S, Cammas FM, Hinson JP \& Clark AJL 1996 Agonist and receptor binding properties of adrenocorticotropin peptides using the cloned mouse adrenocorticotropin receptor expressed in a stably transfected HeLa cell line. Endocrinology 137 3291-3294.

Liggins GC \& Thorburn GD 1994 Initiation of parturition. In Marshall's Physiology of Reproduction, vol 3, pp 863-1002. Ed. GE Lamming. London: Chapman and Hall.

Liggins GC, Kennedy PC \& Holm LW 1967 Failure of initiation of parturition after electrocoagulation of the pituitary of the fetal lamb. American Journal of Obstetrics and Gynecology 98 1080-1086

Lorence MC, Murry BA, Trant JM \& Mason JI 1990 Human $3 \beta$-hydroxysteroid dehydrogenase $/ \Delta 5->\Delta 4$ isomerase from placenta: expression in nonsteroidogenic cells of a protein that catalyses the dehydrogenation/isomerization of c21 and c19 steroids. Endocrinology 126 2493-2498.

Mesiano S, Young IR, Baxter RC, Hintz RL, Browne CA \& Thorburn GD 1987 Effect of hypophysectomy with and without thyroxine replacement on growth and circulating concentrations of IGF-I and -II in the fetal lamb. Endocrinology 120 1821-1830.

Mountjoy KG, Robbins LS, Mortrud MT \& Cone RD 1992 The cloning of a family of genes that encode the melanocortin receptors. Science 257 1248-1251.

Myers DA, McDonald TJ \& Nathanielsz PW 1992 Effect of placement of dexamethasone adjacent to the ovine paraventricular nucleus on adrenocortical steroid hydroxylase messenger ribonucleic acid. Endocrinology 131 1329-1335.
Myers DA, McDonald TJ \& Nathanielsz PW 1993 Effect of bilateral lesions of the ovine fetal hypothalamic paraventricular nuclei at 118-122 days of gestation on subsequent adrenocortical steroidogenic enzyme gene expression. Endocrinology 131 305-310.

Norman LJ, Lye SJ, Wlodek ME \& Challis JRG 1985 Changes in pituitary responses to synthetic ovine corticotrophin releasing factor in fetal sheep. Canadian Journal of Physiology and Pharmacology 63 1398-1403.

Parker KL \& Schimmer BP 1997 Steroidogenic factor 1: a key determinant of endocrine development and function. Endocrine Reviews 18 361-377.

Phillips ID, Ross JT, Owens JA, Young IR \& McMillen IC 1996 The peptide ACTH (1-39), adrenal growth and steroidogenesis in the sheep fetus after disconnection of the hypothalamus and pituitary. Journal of Physiology 491 871-879.

Phillips ID, Anthony RV, Houghton DC \& McMillen IC 1999 The regulation of prolactin receptor messenger ribonucleic acid levels in the sheep liver before birth: relative roles of the fetal hypothalamus, cortisol and external photoperiod. Endocrinology 140 1966-1971.

Picard-Hagen N, Penhoat A, Hue D, Jaillard C \& Durand P 1997 Glucocorticoids enhance corticotropin receptor mRNA levels in ovine adrenocortical cells. Journal of Molecular Endocrinology 19 29-36.

Poore KR, Young IR, Canny BJ \& Thorburn GD 1998 Studies on the role of ACTH in the regulation of adrenal responsiveness and the timing of parturition in the ovine fetus. Journal of Endocrinology 158 161-171.

Ross JT, Phillips ID, Owens JA \& McMillen IC 1997 Cortisol differentially regulates pituitary-adrenal function in the sheep fetus after disconnection of the hypothalamus and pituitary. Journal of Neuroendocrinology 9 663-668.

Received 10 July 2000

Accepted 1 November 2000 